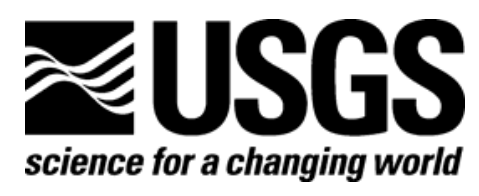

\title{
Digital Data From the Leadville/Buena Vista Aeromagnetic Survey Covering Parts of Chaffee, Eagle, Lake, Park, and Summit Counties, Colorado
}

By Viki Bankey and Goldak Airborne Surveys

Open-File Report 2006-1327

U.S. Department of the Interior

U.S. Geological Survey 


\section{U.S. Department of the Interior DIRK KEMPTHORNE, Secretary}

\section{U.S. Geological Survey \\ Mark D. Myers, Director}

U.S. Geological Survey, Reston, Virginia 2006

For product and ordering information:

World Wide Web: http://www.usgs.gov/pubprod

Telephone: 1-888-ASK-USGS

For more information on the USGS - the Federal source for science about the Earth,

its natural and living resources, natural hazards, and the environment:

World Wide Web: http://www.usgs.gov

Telephone: 1-888-ASK-USGS

Suggested citation:

Bankey, Viki, and Goldak Airborne Surveys, 2006, Digital data from the Leadville/Buena Vista aeromagnetic survey covering parts of Chaffee, Eagle, Lake, Park, and Summit Counties, Colorado: U.S. Geological Survey Open-File Report 2006-1327.

Any use of trade, product, or firm names is for descriptive purposes only and does not imply endorsement by the U.S. Government.

Although this report is in the public domain, permission must be secured from the individual copyright owners to reproduce any copyrighted material contained within this report. 


\title{
Digital Data From the Leadville/Buena Vista Aeromagnetic Survey Covering Parts of Chaffee, Eagle, Lake, Park, and Summit Counties, Colorado
}

\section{By Viki Bankey' and Goldak Airborne Surveys ${ }^{2}$}

\begin{abstract}
This report contains digital data, image files, and text files describing data formats and survey procedures for aeromagnetic data collected during an aeromagnetic survey in central Colorado in October and November, 2002.
\end{abstract}

\section{Introduction}

This report describes data collected from an aeromagnetic survey flown over an area of central Colorado that includes parts of Chaffee, Eagle, Lake, Park, and Summit Counties, including the towns of Leadville and Buena Vista and parts of the Mosquito Range, Gore Range, and Sawatch Mtns. These data were collected by Goldak Airborne Surveys on contract to the U.S. Geological Survey (USGS).

These surveys were designed to complete or extend the coverage of surveys previously acquired in Colorado (Oshetski and Kucks, 2000). Our overall objective in conducting these surveys is to improve knowledge of the subsurface geologic framework in an area of complex and intersecting structural terranes. In this area, the north-trending structures of the Rio Grande rift intersect the older, northeast-trending Colorado Mineral Belt.

\section{Organization of Data}

The "readme.txt" file provides summaries of the file contents. The folders are organized as follows. Files pertaining to this report are contained in the "report" folder; files pertaining to the gridded data are contained in the "grids" folder; files pertaining to the flight-line data are contained in the "linedata" folder; and files pertaining to the color shaded relief images are contained in the "images" folder. In the data folders, ASCII files with the extension ".txt" describe the format and contents of the data files. Please read the ".txt" files before using the data files.

\footnotetext{
${ }^{1}$ U.S. Geological Survey, Denver, CO.

${ }^{2}$ Contractor, Saskatoon, Saskatchewan, Canada.
} 


\section{Description of Data}

Aeromagnetic data are collected using airborne geophysical sensors that measure subtle variations in the Earth's magnetic field. Aeromagnetic surveys are designed to map the variations caused by the irregular distribution of naturally occurring magnetic minerals associated with geologic features.

The aeromagnetic survey (fig. 1) employed a fixed-wing aircraft flying along traverse lines oriented east-west, spaced $400 \mathrm{~m}$ (about 1,300 ft) apart, and flown at a nominal $400 \mathrm{~m}(1,300 \mathrm{ft}$ ) above ground. Orthogonal tie lines were flown north-south at a 3,200 m (10,500 ft) spacing. Total flight-line coverage was $11,448 \mathrm{~km}(7,113 \mathrm{mi})$. The east-west orientation of traverse lines was chosen because it is oblique to the predominant northerly geologic strike of the area. The flight-line data from the contractor are included in this report. Contractor-provided details of the flight specifications, survey procedures, and data processing are included in Appendix A.

A simplified digital elevation grid is provided to represent the ground surface.

\section{Data Processing}

Initial data processing and data reduction were accomplished by the contractor (Appendix A). The additional data and grid processing described in this section was done to display maximum detail while removing unwanted noise and simulating a flying surface draped at a consistent level over terrain.

The magnetic data were interpolated onto a grid at $100 \mathrm{~m}$ intervals. Map projection is Universal Transverse Mercator (UTM), zone 13 (central meridian of $105^{\circ} \mathrm{W}$ longitude, a false easting of 500,000 m, a false northing of $0 \mathrm{~m}$ ), and North American Datum of 1927 (NAD27).

A standard reduction-to-pole operator was applied to the grid. This operation, resulting in reduced-to-pole (RTP) data, corrects for shifts of the main anomaly from the center of the magnetic source that occur at most latitudes owing to the oblique orientation of the measured magnetic field with respect to the Earth's surface (the field is vertical only at the magnetic poles). Declination and inclination of the Earth's field were assumed to be $10.5^{\circ}$ and $66^{\circ}$ respectively for this area. To apply the reduced-to-pole transformation, one must assume that the total magnetizations of most rocks in the study area align parallel or anti-parallel to the Earth's main field.

\section{References Cited}

Oshetski, K.C., and Kucks, R.P., 2000, Colorado aeromagnetic and gravity maps and data-A web site for distribution of data: U.S. Geological Survey Open-File Report 00-0042. [available online at: http://pubs.usgs.gov/of/2000/ofr-00-0042/colorado.htm]. 


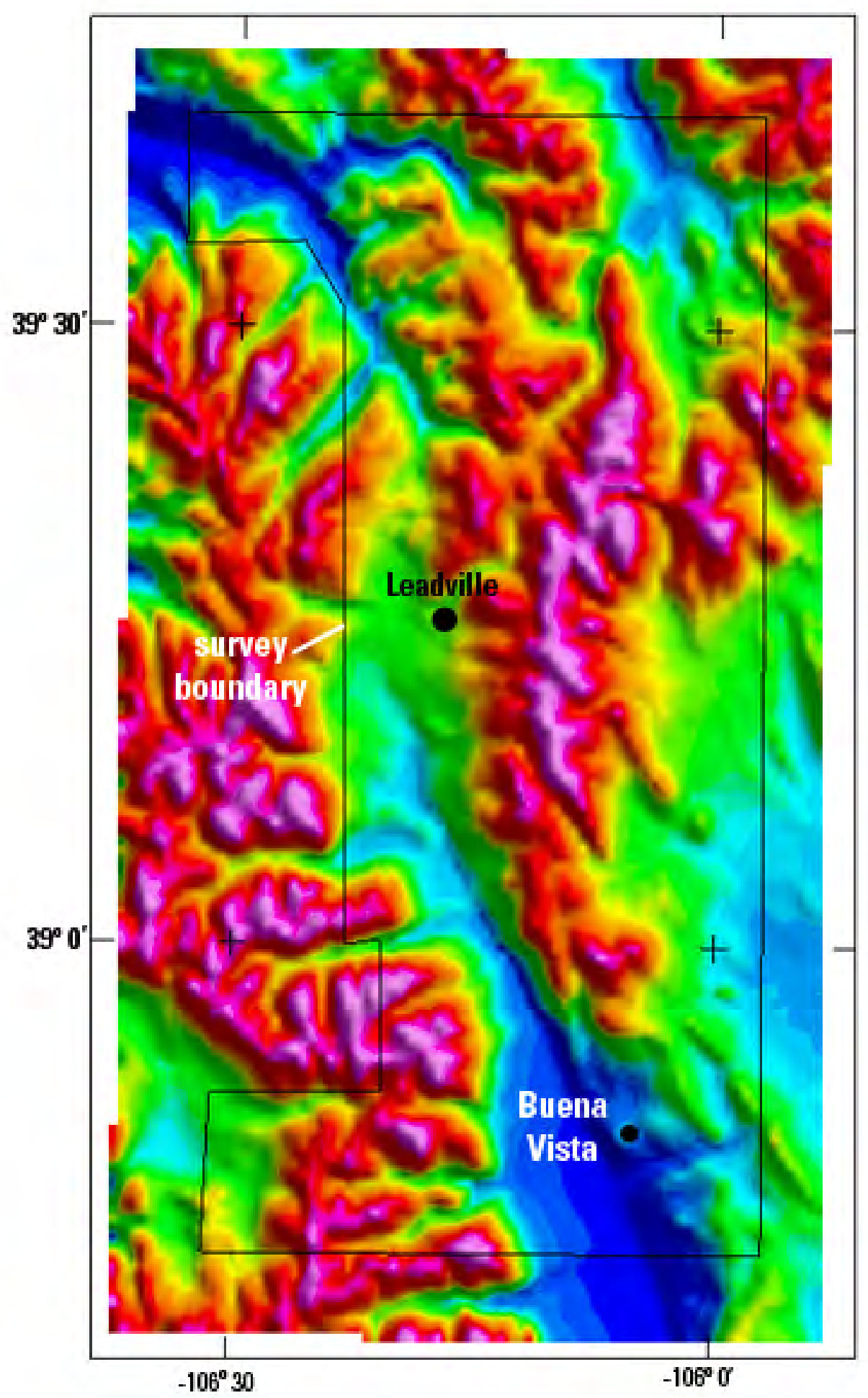

Figure 1. Location map of Leadville/Buena Vista magnetic survey. 